\title{
(DIS)KURZUS A SZTEREOTÍPIÁKRÓL
}

\section{HOFFMANN RITA * - FLAMICH MÁRIA ${ }^{* *}$}

* az Eötvös Loránd Tudományegyetem Pedagógiai és Pszichológiai Karának doktorandusza hoffmann.mariarita@gmail.com

** az Eötvös Loránd Tudományegyetem Pedagógiai és Pszichológiai Karának doktorandusza

flamich.maria@gmail.com

A sztereotipiákon túl; a fogyatékosság irodalmi ábrázolásainak kritikai és kritikus elemzése címmel indult kurzus az ELTE PPK-n azzal a céllal, hogy szépirodalmi és zenemüvek segitségével elömozditsa a fogyatékossággal élö ember sokszinüségének felfedezését, körvonalazza az inkluzív pedagógus tulajdonságait, kompetenciáit. Írásunk azt az utat mutatja be, amelyet a kurzus hallgatói jártak végig, hogy észleljék az évezredes sztereotípiák veszélyeit, felismerjék a fogyatékossággal élö személyeket megbélyegzö szavak, metaforák hatásait, valamint ráébredjenek, milyen szerepet játszik a neveléstudomány és a pedagógus egy befogadó társadalom kialakításában.

És a disszonanciák? Jaume Cabré

\section{Bevezetés}

„Azért mert te fogyatékos vagy, ne hidd, hogy neked mindent lehet!” - ez a súlyos mondat úgy tíz évvel ezelött hangzott el az egyik egyetem doktori kurzusának kutatásmódszertan vizsgáján. Nem tekinthetjük kivételesnek. Számos többségi környezetben tanuló látássérült középiskolás, egyetemi hallgató mesél hasonló megjegyzésről, megdöbbentő tanácstalanságról, drámai kudarcról, pedig a fogyatékosok jelentős hányada - a befogadás reményében - keményen küzd, hogy képes legyen megfelelni a többségi környezet „kihívásainak,” ugyanis - amint azt minden nap tapasztaljuk - a többségi környezet kíméletlenül megköveteli, hogy mindenki teljesítse az általa támasztott elvárásokat. Általában maga is megkísérel szembenézni a „kihívásokkal”, ám gyakran tanácstalanul, esetenként pedig megalapozatlan magabiztossággal - és legtöbbször az érintettek nélkül - dönt a fogyatékosok boldogulásáról. Az a fogyatékossággal élő személy, aki képtelen vagy sajátságosan képes teljesíteni az elvárásokat, egyrészt áldozatul esik ezeknek a döntéseknek, másrészt kirekesztődik. A fentiek alapján kimondhatjuk, létezik egy szakadék a fogyatékos- 
sággal élő személyek és a többségi környezet (pedagógusai) között. Feltételezhetően, legtöbbször a fogyatékossággal élő személyekkel kapcsolatos ismeretek hiányából fakadó bizonytalansággal magyarázható e szakadék, ezért első lépésként, célszerünek tartjuk definiálni, hogy valójában mit jelent a szó, azután példák segítségével szemléltetjük, milyen összefüggésre akadtunk a „fogyatékosság” és „,kihívás" fogalmak között. Mivel feltételezzük, hogy a fogyatékossággal élő személyekről kialakult homályos kép nagy része megöröklött sztereotípiákból tevődik össze, végül azt vizsgáljuk meg, milyen lehetőségeket javasol a kulturális fogyatékosságtudomány a sztereotípiák megértésére, kritikus újragondolására annak érdekében, hogy a befogadás ne jelentsen extra erőfeszítést, problémát, más szóval: kihívást sem a fogyatékossággal élő személynek, sem a többségi környezetnek.

\section{Kihívások, dilemmák}

Mindig odafigyelünk a szóra: „kihívás”, ezért gondoljuk célszerünek, hogy írásunk elején rögtön meghatározzuk, mit jelent. Az angol „challenge” azaz kihívás értelmezése „nehéz munka, olyan helyzettel történő szembenézés, megbirkózás, amely óriási szellemi vagy fizikai erőfeszítést igényel" (Cambridge Dictionary). Az angol nyelvből meghonosodott fogalom értelmezése után, most nézzünk meg egy magyar nyelvü forrást is: „kihívás - feladat, követelmény, megpróbáltatás, próba, próbatétel, teendö [...]" (Zimányi, 2001, 11. o.). Nem nehéz észrevenni, hogy bármelyik meghatározást is olvassuk, így első látásra mindkettő inkább negatív, mint pozitív jelentést sugall. Ebben az értelemben hasonlít egy másik, negatív üzenetet közvetítő szóhoz, ami nem más, mint a „fogyatékosság.”

Arra keresünk választ, hogy ezen a hasonlóságon túl, milyen egyéb köze van ehhez az erőfeszítéshez, próbatételhez, feladathoz a fogyatékosságnak. Vajon hogyan válik e főként negatív konnotációval bíró, divatos fogalom tárgyává a fogyatékossággal élő személy? És főleg, hogyan hat e fogalmi besorolás a fogyatékossággal élő személyek életére? Az alábbi idézetek sejtetnek némi magyarázatot az imént feltett kérdésekre:

„Napjainkban már nemcsak a kihívást kereső, vállalkozó szellemủ pedagógusok kerülnek együttnevelési helyzetbe, hanem bárki találkozhat az osztályában SNI (sajátos nevelési igényü - a szerzök) tanulóval. [...] Az utóbbi évek gyors változása miatt a hagyományos osztályok tanárai elbizonytalanodtak saját szerepükben, [...] nem ismerik az inklúzió lényegét, [...] és csak úgy felülröl végzik.” (Petö, 2011, 143. o.)

„Közismert tény, hogy a pedagógusnak mindig is számtalan kihívásnak kellett megfelelnie, munkája szerteágazó voltához nem fér kétség. [...] az inkluziv pedagógia célja, hogy a hallgatók befogadó, inkluzív magatartást sajátítsanak 
el. Legyenek érzékenyek az esély, a speciális szükséglet és a fogyatékkal (fogyatékossággal - a szerzők) élők problematikájára, toleranciával forduljanak a kevesebb eséllyel rendelkező társadalmi csoportok és konkrét személyek felé" (Gombocz, 2011, 181-182. o.).

Hosszasan folytathatnánk még különböző idézetekkel, ám már e kiemelt néhány sor is egyértelmüen szemléltet valamilyen, a fogyatékossággal élő személyeket érintő bizonytalanságot. A fent idézettek mellett számos további írás beszél elkötelezettségről, kihívásról, ugyanakkor beszámol kétségekről, dilemmákról is. Nemzetközi példák alapján, sorra születnek a befogadást előmozdító jogi megoldások. Rendelkezések, törvények és szakpolitikák garantálják az együttnevelést, a szemléletváltásra azonban, úgy tünik, várnunk kell. De semmiképpen sem tétlenül, hiszen a fogyatékossággal élő személyeket hazánkban a többségi környezet még gyakran sztereotípiák tükrében látja! Amennyiben elfogadjuk, hogy a fogyatékossággal élö személyek oktatása többé nem korlátozódik a gyógypedagógia gyakorlatára, ugyanakkor feltételezzük, hogy a tolerancia elsősorban ismereteken, tapasztalatokon alapul, mindenképpen módot kell találni a hiteles ismeretek megszerzésére, a tapasztalatok értelmezésére, feldolgozására. Ebben a folyamatban ma már nélkülözhetetlenek maguk a fogyatékossággal élő személyek, de segítséget nyújt a kulturális fogyatékosság-tudomány két alábbi komponense is, a fogyatékosság szépirodalmi ábrázolásainak elemzése (Disability in Fiction), valamint a fogyatékossággal élő írók munkáinak tanulmányozása (Disability Memoir). Írásunkban egy, a fogyatékosság szépirodalmi és zenei ábrázolásaival foglalkozó kurzust, és a kurzus kínálta szemléletváltást előmozdító lehetőségeket mutatjuk be.

\section{A (dis)kurzus célja}

Megdöbbentően hangzik, ám mégis igaz, hogy a fogyatékossággal élő személyek csoportja alkotja a „földkerekség legnagyobb kisebbségét” (Riley, 2005, 1. o.), így vitathatatlan, hogy e kisebbség sokféle. Ugyanez a sokféleség már kevéssé jellemzi ábrázolását, hiszen - az ábrázoló személy érzelmei, ismeretei miatt - az ábrázolás gyakran nem objektív. A csoport megítélése is állandóan változik, csakúgy, mint a fogyatékosságé (Flamich és Hoffmann, 2013). „A fogyatékosság talán a legtöbbet változott társadalomtudományi fogalom" (Könczei, 2011). E változások jól tükrözik azt az állandó bizonytalanságot, amely a fogyatékos személyekhez való viszonyulást jellemzi, amióta ember él a Földön. Ezen attitüdbeli változásokat összegzi Bogdan és Biklen 1977-ben publikált írásában is. A két tudós szerint, a müvészeti alkotásokban a fogyatékossággal élő személyeket leggyakrabban az alábbi - mára már sztereotípiákká fejlődött - tulajdonságok jellemzik: szánalmas, védtelen, gonosz, a cselekmény színesítése céljából alkalmazott háttér-karakter, szuperhős, szuper tulajdonságokkal, nevetséges, saját maga ellensége, önmagát sajnálja, és ez akadá- 
lyozza meg befogadását, teher, aszexuális, képtelen részt venni a társadalom életében. Az állandó, attitüdbeli változások ma is megfigyelhetők, hiszen folyton további sztereotípiákkal egészül ki az immár „klasszikus” lista.

A fogyatékossággal élő személyek ábrázolásaiból arra következtethetünk, hogy róluk - egyre nyilvánvalóbb jelenlétük ellenére - még mindig elsősorban megöröklött sztereotípiák mentén gondolkodunk. Ezekre az évezredes sztereotípiákra reflektált az a szépirodalmi müveket elemző, szabadon választható kurzus, amelyet az ELTE Pedagógiai és Pszichológiai Kara indított a 2012/2013-as tanév tavaszi szemeszterében. A sztereotípiákon túl; a fogyatékosság irodalmi ábrázolásainak kritikai - és kritikus - elemzése címü kurzus egyik célja az volt, hogy megkönnyítse a többségi környezet leendő pedagógusainak és sokszínű - gyakran fogyatékossággal élő - tanulóinak a diverzitás és egymás megismerését, valamint a fogyatékossággal kapcsolatos sztereotípiák újragondolását, átértelmezését. Ebben a folyamatban nélkülözhetetlen a kulturális fogyatékosságtudomány, amely interdiszciplináris jellegéből adódóan, a szépirodalmat és a zenetudományt, e két illusztratív ágenst is segítségül hívja, hogy objektíven és kritikusan közelítse meg a sztereotípiákat.

\section{A (dis)kurzus prekoncepciója, szerkezete}

A (dis)kurzus kiindulópontjául az alábbi feltételezésünk szolgált: a fogyatékossággal élő személyek többségi környezetben történő oktatását azért illetik gyakran a nem közömbös „kihívás” szóval, mert a fent említett bizonytalanság, illetve a megöröklött sztereotípiák megelőzik az érintett személyek jelenlétét egy-egy osztályban, egyetemi csoportban. Ez a bizonytalanság - feltételezésünk szerint - úgy küszöbölhető ki, hogy első lépésként, felismerjük, majd megvizsgáljuk saját sztereotípiáinkat és viszonyunkat a fogyatékossággal élő személyekhez mindenkori társadalmi jelenlétük és megítélésük tükrében.

A kiválasztott olvasmányokban felfedezett sztereotípiákat alapvetően az alábbi szempontok szerint figyeltük meg: vélekedés-alapú sztereotípiák, mint karakterkiegészítő, hangsúlyozó eszközök, és valóság-alapú sztereotípiák, mint az emberi különbözöség szemléltetésének eszközei. Természetesen, mivel sok esetben nehéz elhatárolni a kétféle ábrázolást, találkozhatunk átfedésekkel. Az olvasmánylista összeállításánál egyik célkitüzésünk az volt, hogy a fogyatékossággal élö személyek ábrázolását - elsősorban - szépirodalmat müvelö írók (például: Shakespeare, Tolkien, Karinthy, Steinbeck, Cabré) müveiben figyelhessék meg hallgatóink. A szépírók által alkalmazott sztereotípiák kiemelésével, arra törekedtünk, hogy igazoljuk a sztereotípiák több évszázados létezését. A sztereotípiák lehető legobjektívebb megfigyelése érdekében törekedtünk arra is, hogy amennyiben lehetséges - kerüljük a fogyatékosságra fókuszáló, népszerủ irodalmi alkotásokat, ezért olvasmánylistánkból kihagytunk néhány sikerorientált mủvet, mint például Kesey: Száll a ka- 
kukk fészkére és Keyes: Virágot Algernonnak címü regényét. A fogyatékossággal élő személyek egyre nyilvánvalóbb jelenléte azonban - természetesen - indokolta néhány fogyatékosságra fókuszáló mủ felhasználását is, így a kiválasztott müvek vagy fogyatékossággal élö írók alkotásai voltak (Bourne, Böszörményi, Kleege), vagy mindeddig szokatlan témát mutatnak be (Sinapi, Tímár).

A fogyatékosság-felfogás változásaihoz, mások és a magunk által megfogalmazott sztereotípiákhoz az alábbi útvonalon közelítettünk:

1. A fogyatékossággal élő személyek ma jellemző jelenléte.

2. Pozitív és negatív elöítéletek.

3. Feltételezett forrásaik.

4. Művészeti visszatükröződések.

5. A fogyatékossággal élő személyek tudatformáló felelőssége.

6. A pedagógusok tudatformáló felelőssége.

A (dis)kurzusok során egy interjút, tizenkét szépirodalmi alkotást, két filmet, továbbá öt kisfilmet vizsgáltunk és vitattunk meg.

Mint már említettük, feltételezésünk szerint, a fogalmi és felfogásbeli változások megértésében és saját attitüdünk tisztázásában játszik jelentős szerepet a fogyatékosság irodalmi ábrázolásainak kritikus elemzése, ezért az olvasmánylista összeállításánál kiemelt szempont volt, hogy megkönnyítsük a hallgatók orientációját, így a jelen helyzetböl, a mindennapokból kiindulva kerestük a hallgatókkal a sztereotípiák gyökereit mesékben, mítoszokban, szépirodalmi alkotásokban, majd a modellek, konstrukciók, paradigmák változásait megfigyelve érkeztünk vissza a jelenbe. A fogyatékosság diverzitásának szemléltetését a korábban említett fő szempontok mentén az alábbiak szerint építettük fel: Én-kép; Mesehősök, mesés hősök; Képzelet és valóság; Torz testben torz lélek(?); Torz test és szex; Sajátos világ, sajátos világlátás; Veszélyes metaforák; Saját élmény saját szavakkal; Súlyos döntések; Magányos szülő, magányos gyerek; A fogyatékosság vállalása; A fogyatékosság elviselése; Fogyatékosok a felsőoktatásban; Akadálymentes prezentáció; A fogyatékosság ignorálása vagy elfogadása, alázat.

\section{Gúszi $^{1}$, Lennie, Thomas és a többiek}

Hisszük, hogy a hallgatók elöször saját fogyatékosság-felfogásukat, s magukat helyezzék el azon az úton, amelyen együtt indulunk el, és haladunk, hogy megfigyeljük a fogyatékossággal élő személyek megítélésének változásait, és önmagunk szemléletének formálódását. Ezért volt kiindulópontunk szükebb környezetünk,

\footnotetext{
${ }^{1}$ Gúszi (Gyuszi): Böszörményi Gyula, Kucó című kisregényének egyik szereplője, aki nem más, mint maga az író.
} 
Magyarország. Első lépésként a hallgatók a közelmúltbéli és a mai helyzetről tájékozódtak egy interjú alapján, amely Böszörményi Gyula közismert mozgássérült íróval készült. Az interjú arra ösztönözte a hallgatókat, hogy bevezetésképpen elgondolkodjanak, hogy látja saját megítélését egy népszerü, fogyatékossággal élö személy, és felfedezzék a köztudatban leggyakrabban megjelenő sztereotípiákat és azok hatásait, így felhívhattuk a figyelmet azokra a morális, medikális, szociális, emberi jogi modellekre (Kálmán és Könczei, 2002; Könczei, 2011), amelyek a fogyatékossággal élő személyek megítélését, ábrázolásait csoportosítják. A fogyatékosságtudomány teoretikus megközelítése, az ismeretek megalapozása céljából az első alkalommal hallgatóink számára érthetővé tettük, hogy ,a 'modellek' gondolati konstrukciók, amelyek szerint a fogyatékosságról való gondolkodás és cselekvés létrejön" (Könczei, 2011). A hallgatók azt is megsejthették, a modellek, bár jól példázzák az időbeli felfogás-változásokat, mégsem kizárólag lineárisan rendelhetők egymás mellé, hiszen a valóságban gyakran párhuzamosan, olykor egymással versengve léteznek. Csupán néhány modellt emeltünk ki, így már első alkalommal is világosan kirajzolódott, hányféleképpen viszonyul a társadalom a fogyatékossággal élő személyekhez, hogyan kelnek életre a sztereotípiák, meghatározva „a Föld legnagyobb kisebbségének" mindennapjait.

A második alkalommal még mindig törekedtünk az „otthon” biztonságára. Az első találkozásunkkor meghallgatott Böszörményi Gyulával készült interjúban említett Kucó címủ monodráma volt ebben segítségünkre. A hallgatók megismerkedhettek a medikális modell egyik jelenségével, az egészségügyi gyermekotthonnal, amely kiválóan példázza a modell tipikus szemléletét: ha nem lehet a fogyatékos személyt megjavítani, el kell dugni. Az egészségügyi otthonok lakóira jellemző, a müben megfogalmazott gyerek státusz: „Amíg a gyermekotthonban vagy, gyerek vagy!" meghökkentő igazságnak bizonyult.

Számos egyéb kérdés is felvetődött a monodráma (majd később valamennyi elemzett mü) segítségével, amelynek részletes ismertetése ebben az írásban helyhiány miatt nem lehetséges, egyet azonban mégis elgondolkodtatónak tartunk. A hallgatók igyekeztek magyarázatot találni a kérdésre, miért gondolta úgy az író, hogy szavait egy enyhén értelmi sérült szereplő tolmácsolja. Magyarázható-e ez is egy, a mesékben jól bevált sztereotípiával, mely szerint, a királyság fogyatékosságait csak az udvari bolond fedheti fel?

Következő találkozásunkkor elindultunk, hogy megkeressük, honnan erednek a müben felfedezett sztereotípiák. Így léptünk vissza időben a morális modellhez. A mese és mitológiai hösökben hallgatóink felismerték a jelenlegi vélekedések gyökereit. Választott olvasmányaink egy gyermekeknek írott mese, Andersen: A kis hableány, és egy felnőttekhez szóló irodalmi mü Tolkien A gyürük ura: Smeagol megszelíditése voltak. Feltettük a kérdést, a mesék mennyiben felelősek az elöítéletek kialakulásáért. Mit rejt a más, a torz megjelenés? Vizsgáltuk a morális modellre jellemző fogyatékosság-felfogás két alapvető elemét, a testi és/vagy szellemi fo- 
gyatékosság ábrázolásait. Hallgatóink felfedezték, különböző kultúrák különbözö társadalmai egymástól eltérően viszonyulnak a testhez, a szellemhez, és ez a különbözőség valamennyi kultúrában meghatározó (Kálmán és Könczei, 2002. 29. o.). Megállapítottuk, hogy a morális modellhez képest ma fogyatékosság-felfogásunk árnyaltabb, mivel tudomást vesz a látható fogyatékosság mellett annak láthatatlan alternatívájáról is.

Néhány mese- és mitológiai hős jellemének megfigyelése alapján megvizsgáltuk a megszokottól eltérö lét kapcsolatát a transzcendenciával. Világossá vált, hogy a morális modell miféle gondolati konstrukciót tükröz; a fogyatékosság, mint ahogy maga a fogyatékossággal élő személy is, Isten büntetése. Andersen és Tolkien müvei utat nyitottak, hogy a különböző kultúrák tükrében is megvizsgáljuk, hogyan jelenik meg ez a „büntetés”, melyekről feltételezzük, hogy a fogyatékosság sztereotípiáinak forrásai. A különböző kultúrákba való bepillantás során kiderült, a zsidóság fogyatékosság-felfogása ellentmondásosnak tủnik, mivel elfogadja Mózes fogyatékosságát, ugyanakkor törvényei szigorúan rendelkeznek a fogyatékos személyeket megillető jogokról, kiváltságokról. Az egyiptomi kultúrkörben találkoztunk törpe istenekkel. ${ }^{2} \mathrm{Az}$ antik görög kultúra egészség- és szépségszemlélete valamilyen értelmezésben ma is jelen van a fogyatékosságról kialakult képben. Hallgatóink megtudták, hogy az ókori görögök ,a fizikai fogyatékosságot szinte sosem párosították automatikusan jellembelivel is" (Kálmán és Könczei, 2002, 39. o.). A spártai fogyatékosság-felfogás értelmezése gyakran vált ki vitát itthon, és mivel visszatérően megjelenik, mi sem hagyhattuk szó nélkül. A római birodalomban élő fogyatékosság-konstrukcióikal, az ép testben ép lélek felfogással ${ }^{3}$ is megismerkedtek a hallgatók.

A korábbi alkalmakhoz hasonlóan, a sztereotípiák eredetét vizsgáló találkozásunkkor ugyancsak számos kérdés, gondolat vetődött fel, például:

- Vajon az ember saját agressziójától akar-e megszabadulni, amikor torz lényeket alkot?

- Létezik-e átjárhatóság a fogyatékosok világa és a nem fogyatékosok világa között?

- Létezik-e egyáltalán két külön világ?

- A fogyatékosság, mint fogalom taszít, a fogyatékos egyén vonz, ismerkedésre bátorít?

A fogyatékosság ábrázolásainak megfigyelése közben minden alkalommal példákat kerestünk, hogy illusztráljuk annak zenei jelenlétét, ábrázolásait. Itt Richard Wagner:

\footnotetext{
${ }^{2}$ Egyiptomi törpe istenek, például Ptah-nak is volt törpe alakja. Ptah Memphis emberi alakban ábrázolt föistene, aki a világot teremtette (Kálmán és Könczei, 2002, 37. o.).

${ }^{3}$ Ép testben ép lélek. Decimus Iunius Iuvenalis I. század közepén Rómában élt szatíraírótól származó mondás (Kálmán és Könczei, 2002, 44. o.).
} 
A Rajna kincse címü operájából hallgattunk részleteket, és figyeltük meg a zenei hangokban a fogyatékosság megjelenését.

A misztikus hösöket egy misztikus karakter követte. Kafka 1915-ben kiadott (Drabble, 2000) Az átváltozás címü müvét elemeztük, amelyben a föhős, Gregor Samsa egy reggel arra ébredt, hogy féreggé változott. Lassú átváltozását és családja reakcióit figyeltük meg. A mü elemzése során felmerült gondolatok érdekes összefüggéseket, megfigyeléseket hoztak felszínre. Beszéltünk a novella kulturális különbségekből adódó értelmezéseiről is, mivel egy nemzetközi fogyatékosságtudományi levelezölistán (Disability Research List) egy japán tudós humort vélt felfedezni a Kafkai ábrázolásban.

Mint ez már bevett gyakorlattá vált, e novella kapcsán is számos kérdést, gondolatot vetettek fel a hallgatók. Ezek között szerepelt a kiszámítható másság, azaz a magzat vizsgálata, a váratlan átváltozás, például valamilyen baleset és esetleges következményei. Beszéltünk a fogyatékos gyermekek helyzetéről a többségi iskolákban; gyakorlati megoldásokat kerestünk a kérdésre, milyen feladatkiosztási technikák segíthetik a befogadást? Megoldás-e a csoportmunka? Felvetődött a torz test látványa, elfogadása is. Ennek megértéséhez, megvitatásához Nick Vujicic, végtagok nélkül született motivációs tréner és prédikátor középiskolásoknak szóló előadásai nyújtottak segítséget. Hallgatóinkat arról is megkérdeztük, milyen más hivatást tudnának elképzelni a trénernek. A fogyatékosság zenei ábrázolásaihoz ez alkalommal Richard Strauss Metamorfózisok címü mủve szolgáltatott példát.

Az ép testben ép lélek meghatározás nyomán adódik a kérdés: Torz testben torz lélek? Ismeretes, hogy az eltérö, torz testhez gyakran rendeltek negatív tulajdonságokat a szépirodalom kiemelkedő képviselői is, hiszen természetesen követték a korukra jellemző fogyatékosságra vonatkozó gondolati konstrukciókat. A morális modell szerinti fogyatékosság-ábrázolás egyik kiemelkedő alkotásában, Shakespeare III. Richárd címü müvében figyelték meg hallgatóink ezt a gyakorlatot. III. Richárd mellé számos szereplö, regényalak sorakozott fel, néhányan valóban rosszindulatúak, mint maga III. Richárd, néhányuk torz külseje azonban érző szívet is rejt, például Quazimodo vagy Rigoletto. Ök azonban mind évszázadokkal később születtek, és sugallnak egyfajta elmozdulást az ember rejtett értékeinek megismerése és a rossz tulajdonságok lehetséges megjavítása, azaz a morális modelltől a medikális modell irányába.

A torz test még ma is gyakran vonz kíváncsi tekinteteket, és mint ilyen, a sztereotípiák tárháza. Következésképpen talán épp ezért, a fogyatékossággal élő személyek egyik leggyakoribb sztereotipikus ábrázolása az aszexualitás Bogdan és Biklen klasszikus felsorolása szerint. A sztereotípia igazságtartalmát keresve, Jean Pierre Sinapi: Légyott a hetesen címü 2001-ben készült filmjét néztük meg. A film egy kirekesztett és részben kirekesztő világot mutat be, és számos aspektusból hasonlítható Böszörményi Kucójához, számos egyéb aspektusból azonban szembe is állítható vele. Mindkét mủ rávilágít a gondozottak gyermek-szerepére, de hasonló- 
ságok figyelhetők meg az otthon hierarchiáját illetően is. Érdekes volt megfigyelni a kulturális különbözőségből adódó felfogásbeli hasonlóságokat és eltéréseket. Sinapi filmje az alábbi gondolatokat vetette fel: Mit jelenthet a torz test látványa: elvárható-e a szex, és létezhet-e a torz testre irányuló szerelem? Szóba kerültek továbbá a fogyatékosok családalapítási álmai és a valóság. És felmerült a kérdés: Hogyan segíthet a társadalom a fogyatékos szülőknek? Sinapi a nyitni vágyó zárt közösség, valós elemeken nyugvó, ábrázolásának megbeszélése után, Herbert George Wells Vakok országa címü müvében inkább a fikcióba rejtett valós elemeket kerestük. Elgondolkodtunk azon, mit jelent, igaz-e a novellában hangsúlyos közmondás: „A félszemü király a vakok országában.” Eltünődve a szavak megbélyegző erején, további közmondásokat és metaforákat gyüjtöttünk.

Immár nem elöször merült fel a kérdés: Van-e külön világ? Ezúttal azonban válasz is érkezett: Van, de csupán annyiban, mint ahogy minden ember egy külön világ, minden közösségnek, szubkultúrának is vannak sajátosságai, közös pontjai, külön világa. Hallgatóink szerették volna megtudni, mi szép a vakok számára és mi nem. Így az alábbi kérdések merültek még fel: Milyen anyag érintése, tapintása jelent élményt? Hogyan lehet berendezve egy vak ember lakása? Harmonizálnak-e a színek körülötte? Mi alapján tájékozódnak, igazodnak el a városban és faluban? A vakok közössége fél-e jobban a látók közösségétől, vagy fordítva, a látóké a vakokétól? Milyen tudás, tapasztalat szerezhető sötét szobákban, kiállításokon? Milyen tudást közvetítenek a „tapasztalati szakértők”? Egyértelmü megfogalmazást nyert, hogy másképp éli át a fogyatékossággal élő ember az úgynevezett érzékenyítéseken, kiállításokon prezentált élethelyzetet, mint a nem fogyatékos. A vakságot, mint gyakran alkalmazott metaforát Karinthy Frigyes Géniusz címü müve alapján elemeztük tovább. Érdekes volt a két különböző kultúra közti hasonlóság a vaksággal kapcsolatos felfogásokat illetően is. A sztereotípiák állandó jelenlétét Tímár Péter Vakvagányok címü filmjének részletei illusztrálták. Annak ellenére, hogy a film hallatott egy keveset a vakok saját hangjából, hallgatóink meglátása szerint inkább a vakokat kevéssé ismerő külső környezet értetlensége és sztereotípiái jutottak kifejezésre.

Mint az eddigiekből kiderül, csak nyomokban ragaszkodtunk a kronológiához. Sokkal fontosabbnak tartottuk a tematikus megközelítést, kapcsolódást, ezért a fogyatékos személyek média-megjelenéseinek megbeszélése nyomán elindultunk, hogy megkeressük azokat a pontokat, ahol az érintettek müvészként, tudósként hallatják már saját hangjukat. Így ismertettük meg hallgatóinkat a fogyatékossággal élő írók önéletrajzi ábrázolásaival, azaz a Disability Memoir-ral ${ }^{4}$, és annak egy korai esszé-

\footnotetext{
${ }^{4}$ Disability Memoir (fogyatékosság-memoár) az amerikai irodalom memoár szakértői szerint a műfaj valójában Helen Keller (1880. június 27 - 1968. június 1.), amerikai siketvak író, újságíró, fogyatékosügyi aktivista, oktató, nevelö írásaival kezdődött.
} 
jével: Randolph Siliman Bourne, (1913) Fogyatékosságok bölcselete címü, kemény, szókimondó írásával.

A fogyatékosság, mint saját élmény leírása mára már egyre szélesebb körben alkalmazott, ám olykor vitatott (Kleege, 2011/2012) módszer az esélyegyenlőséget szorgalmazó, pozitív szemléletváltáshoz kapcsolódóan. Ennek az új keletủ irodalmi müfajnak egyik első alkotása az idén száz éves esszé, amely érdekes, korábban szokatlan oldalról közelít a fogyatékosság felé, hiszen felhívja a figyelmet arra, mit tegyen a fogyatékossággal élő személy a többségi környezetbe történő beilleszkedés érdekében, ugyanakkor a többségi környezetnek is segít azzal, hogy megmagyaráz néhány fogyatékos személyeket érintő sajátosságot.

Száz év és a bölcseletek tükrében megnéztük azokat a reklámfilmeket, amelyek a közelmúltban készültek itthon, hogy pozitív irányba formálják a társadalom fogyatékossággal élő személyekkel kapcsolatos tudatát. A kisfilmekben jól láthattuk, - mint ahogy már Wells és Karinthy írásaiból is kiderült - a fogyatékosoknak sem kell a szokatlan, ők is kirekesztőek. Megtudhattuk, hogy ugyanolyan indulatosak, mint bárki más, és azt is megfigyelhettük, hogyan mondunk róluk, a fejük fölött ítéletet, és leszögeztük, a felhívás, hogy többet tudjunk meg róluk, csak üres felhívás marad, hiszen honnan tudhatnánk meg bármit is Róluk, ha nem olvassuk írásaikat, ha nem akarjuk meghallani a hangjukat, megérteni szavaikat. Ha elsősorban a magunk elképzelései szerint vagyunk hajlandóak látni öket... Így merült fel az alábbi két kérdés: Van-e teljes integráció és inklúzió? Kik a vesztesei?

Az integráció és inklúzió kérdése újabb szépirodalmi forrásokat kínált. Mi a témával kapcsolatos beszélgetések vitaindítójául John Steinbeck: Egerek és emberek címü alkotását választottuk. Fogyatékossággal élő személyekkel csupán ritkán találkozó pedagógus hallgató számára tanulságos kérdéseket vet fel ez a kisregény. Megfigyelték hallgatóink, hogy Lennie el- és befogadása érdekében George sajátosan tolmácsolja Lennie-nek az őket körülvevő világot, embereket, azaz a többségi környezetet. George interpretációjában gyakran konkrét dolgok szolgálnak absztrakciók és érzelmek kifejezésére is. Hallgatóinkban megfogalmazódott, hogy meg kell értenünk a másik ember szándékát akkor is, ha ő sajátos értelmezésben képes interpretálni azt. Fontos észrevétel volt a szinte mindig ugyanazokkal a szavakkal, hangsúllyal elmesélt álom is, amelyet George mindig azért ismételt el, hogy Lennie elhelyezze magát a világban, meggyőződjön George szeretetéröl. Lennie lelövése kapcsán nem kevés szó esett a fogyatékos személy méltóságáról, mint ahogy beszéltünk arról is, hogy a kirekesztettek saját együttélési közösséget alkotnak rövid idő alatt, ez azonban még nem jelent valódi összetartozást, így összetartást sem. Ezen az úton jutottunk el a többségi környezetben élő, a fogyatékossághoz valamilyen módon kapcsolódó ember lassan kialakuló magányához. Górcső alá vettük a szülő és a gyermek elmagányosodását egyaránt. 
A fogyatékosságról, mint az elmagányosodás egyik tényezőjéről két fikció, Jaume Cabré (2000): Ballada és Gottfried Heinrich álma ${ }^{6}$ címü novellái alapján kezdtünk el beszélgetni. A megindító Ballada a hallgatókat az alábbi felismerés kimondására késztette.

A fogyatékos gyereket nevelő szülő gyakran magányossá válik, külön világban él. A közvetlen környezete is bizonyos távolságot tart vele szemben, a fogyatékosság miatt számos család bomlik fel. Gottfried Heinrich álma kapcsán pedig azt sikerült megérteni, minden szülői törekvés, szándék, szeretet ellenére gyakran magányos marad az a személy, aki sajátosan, vagy egyáltalán nem kommunikál. Felvetődött az a kérdés is, milyen mértékben és hogyan léphetünk be ebbe a sajátos magánszférába. Természetesen, a két novellából kiindulva az értelmi sérültek manipulálhatóságáról is szó esett, így néhány gondolat erejéig visszakanyarodtunk Steinbeck kisregényéhez.

Miután hallgatóink képet kaptak a világ sajátos érzékelésének és értelmezésének egy újabb módjáról, elkezdtük közösen mérlegelni, hányféle szempont játszhat szerepet abban, ahogyan a pedagógusnak kellene közelíteni összetett, sokszínü osztálya, hallgatósága felé.

Még részben a fogyatékosság és magány témakörére visszatekintve, Georgina Kleege (2006) Disabled Students Come Out; Questions without Answers címü esszéje nyomán érdekes megközelítéssel ismerkedtek meg hallgatóink. Az írás ugyanis azt a mindmáig szokatlan észrevételt összegzi, amely szerint jól képzett, felkészült fogyatékos oktatók jelentős szerepet játszhatnak abban, hogy egyrészt láthatatlan fogyatékossággal élő hallgatók merjék vállalni fogyatékosságukat többségi környezetben, másrészt, hogy a fogyatékossággal élö hallgatók ne stigmának éljék meg saját fogyatékosságukat. Ezen észrevétel Kleege-nek a University of California, Berkeley Angol Tanszékén szerzett saját élményén alapul, és ma még nem nyert bizonyítást, de azt mindenképpen sugallja, hogy fogyatékossággal élő oktatóknak helye és óriási felelőssége van a (felső)oktatásban.

Az emberi diverzitás ismeretének és tiszteletének gyakorlati összegzésére a kurzus végén egy akadálymentes prezentáció elkészítését vállalták a hallgatók. Egy valóban akadálymentes prezentáció létrehozásához az alábbi ismérveket határoztuk meg: áttekinthetőség és hozzáférhetőség. Megállapítottuk, egy akadálymentes prezentáció esetében a PPT mindenképpen áttekinthető, egyszerüen követhető. Jóllehet a hazánkban alkalmazott gyakorlat szerint a PPT nem az előadás „vázlata”, hanem „kiegészítője”, mégis, pontokba szedett tartalma be kell, hogy épüljön az előadás szövegébe. Ikonok segíthetnek a figyelemfelkeltésben. Hallgatóink a kurzuson szerzett ismeretek alapján megfogalmazott áttekinthetőségre, hozzáférhetőségre vonat-

\footnotetext{
${ }^{5}$ Cabré, Jaume: Ballada. A fordítás az író nagyvonalú hozzájárulásával készült, kizárólag a kurzus hallgatói számára és oktatási célra használható fel.

${ }^{6}$ Cabré, Jaume: Gottfried Heinrich álma. A fordítás az író nagyvonalú hozzájárulásával készült, kizárólag a kurzus hallgatói számára, és oktatási célra használható fel.
} 
kozó elgondolásait, egy általuk választott olvasmány- vagy filmélmény prezentációján keresztül ismerhettük meg az utolsó alkalommal, amikor a hallgatók mutatták be az Embert, aki mellesleg fogyatékossággal élő, valós, vagy elképzelt személy. A prezentációk megtervezésénél és előadása során fontos szempont volt az akadálymentesség, azaz a fent bemutatott áttekinthetőség, hozzáférhetőség: a PPT színeinek, betűméretének látássérült szempontok alapján javasolt kiválasztása, a PPT szövegeinek beépítése az előadásba, a prezentáció szövegének követhetősége, valamint az érthető előadásmód. A hallgatók által választott és bemutatott müvek: Lessing, Doris (2008): Az ötödik gyerek; Groom, Winston (1985) Forrest Gump címü regénye alapján készült Zemeckis, Robert (1994) azonos címmel rendezett filmváltozata és Andersen A rút kiskacsa címü meséje. A bemutatott müvekkel kapcsolatos, azokból kiinduló beszélgetést a hallgatók vezették, moderálták.

A (dis)kurzust Thomas Quasthoff és Bobby McFerrin egyik közös felvételével zártuk. A felvételt nézve leszögeztük, hogy amíg nem tanuljuk meg vagy fogadjuk el, hogy számos módja létezik a világ érzékelésének, addig minden egyesítést szorgalmazó törekvés ellenére, létezik két világ és csupán keveseknek sikerül elfogadtatni, elismertetni tehetségüket, adottságaikat. Hallgatóink azt is megfogalmazták, hogy legtöbb sikeres, elismert fogyatékos személy mellett, mögött jelen van a szerető, elfogadó, befogadó család és legalább egy pedagógus.

\section{Diszkusszió}

A sztereotípiákon túl; a fogyatékosság irodalmi ábrázolásainak kritikai - és kritikus - elemzése címü kurzust három hallgató vette fel, és töltötte ki a kurzus szerepét vizsgáló, húsz plusz egy kérdést tartalmazó kérdőívet. Mindhárman egyértelmủen leszögezték, hogy az egyetemek kurzuskínálatában szerepelnie kellene fogyatékossággal kapcsolatos, elemző kurzusoknak, mivel ma világszerte inkluzív társadalom megvalósítására törekszünk. Jóllehet, a vizsgálatot kutatásnak nem, olyan jelzésértékü esettanulmánynak azonban kétségtelenül tekinthetjük, amely számos további kérdést vet fel, például: Milyen egyéb módokon lehet és célravezető megismerkedni a fogyatékossággal élő személyeket ma még elsősorban sztereotípiák övezte világ valóságtartalmával? Ez utóbbi felvetés további kérdéseket és kutatásokat sugall, amelyek részletesen vizsgálhatják a fogyatékossággal élő oktató nem elhanyagolható szerepét a többségi oktatásban. Helen Keller (1903) írja: „Az oktatás, nevelés legjelentősebb eredménye a tolerancia". A siketvak író, gondolkodó toleranciáról igen, ám „kihívás”-ról nem beszél. Még mielőtt a „kihívás” is felvésődik újabb megbélyegző sztereotípiaként a korábban már ismertetett listára, érdemes elgondolkodni azon, hogy a világ sokféleképpen élhetö, és egy nyitott, toleráns világ megvalósításában figyelemre méltó helye van a fogyatékos oktatónak, írónak, tudósnak - általában a fogyatékossággal élő embernek, mert a diverzitás tisztelete 
és egymás értékeinek megismerése nélkül saját helyünket megtalálni mindenkinek nagyon nehéz feladat, egyszóval: kihívás.

\section{Irodalom}

Bogdan, R. - Biklen, D. (1977): Handicapism. Social Policy, March/April 14-19.

Böszörményi Gyula interjú (Kossuth Rádió, Arcvonások 2013. január 3.)

Cabré, Jaume (2000): Gottfried Heinrich álma In: Viatge d'hivern. Fordította: Flamich Maria, Hoffmann Rita Kézirat. Proa, Barcelona, 125-138.

Cambridge Dictionary: URL: www.dictionary.cambridge.org/dictionary/british/challenge_1 Letöltés ideje: 2013. 07. 13.

Disability Research List: URL: www.jiscmail.ac.uk/lists/disability-research.html Letöltés ideje: 2013. 07. 13.

Drabble, Margaret (ed.: Sixth edition, 2000): The Oxford Companion to English Literature. Oxford University Press. Oxford, New York.

Flamich Maria, Hoffmann Rita (2013): A sztereotípiákon túl - a fogyatékosság irodalmi ábrázolásainak kritikai, és kritikus elemzése. A Kulcskompetenciák fejlesztése a formális, a nem formális valamint az informális tanulás során a társadalmi kohézió és esélyegyenlöség érdekében. Konferencia, Veszprém. Kézirat

Gombocz Orsolya (2011): Inkluzív pedagógia a Pázmány Péter Katolikus Egyetem Bölcsészet- és Társadalomtudományi Karán. Pedagógusképzés. 3-4. sz. 181-185.

Kálmán Zsófia, Könczei György (2002): A Taigetosztól az esélyegyenlőségig. Osiris Kiadó, Budapest.

Keller, H. (1903): Optimism: An Essay. The Merrymount Press, Boston.

Keller, H. önéletrajza: URL: www.biography.com/people/helen-keller-9361967 Letöltés ideje: 2013. 09. 20.

Kleege, G. (2011/2012b): Disability Memoir. Course description 180A - Manuscript.

Kleege, G. (2006): Disabled Students Come Out: Questions without Answers. In: Thompson Ibrahim, Ch. (2011): An Anthology Of Disability Literature. Durham, NorthCarolina: Carolina Academic Press. 307-316.

Könczei György (2011): 20 év: a megbámult végre visszanéz. URL: www.specialpecs.hu/ wp-content/uploads/2011/03/20_ev.ppt Letöltés ideje: 2013. 09. 09.

Pető Ildikó (2011): Az inkluzív nevelés és a debreceni tanárképzés. Pedagógusképzés. 3-4. sz. $143-152$.

Riley, Charles A. (2005): Disability and the Media; Prescriptions for Change. University Press of New England. Lebanon, United States of America

Vujicic, Nick: Te erös leszel a végén? URL: www.youtube.com/watch?v=Q4f_UNMNOMIA Letöltés ideje: 2013.09. 09.

Zimányi Árpád (2001): Nyelvhelyesség. II. Rész Szavak és állandó szókapcsolatok helyes használata. Részletek a szerző Nyelvhelyesség címü jegyzetéböl. EKF Líceum Kiadó, Eger. URL: www.nyeomszsz.org/orszavak/pdf/Zimanyiszokapcsolatok.pdf Letöltés ideje: 2013. 08. 30 . 
A kurzuson felhasznált olvasmányok, filmek, kisfilmek, blog-bejegyzések, egyéb hivatkozások:

Andersen, H. Ch.: A kis hableány.

Arcvonások. Interjú Böszörményi Gyulával. Kossuth Rádió, 2013. 01.03.

Bourne, Randolph Siliman (1913) Fogyatékosságok bölcselete. In: Országh László (1974, szerk.) Az el nem képzelt Amerika. Európa Könyvkiadó, Budapest. 405-414.

Böszörmény Gyula (1997): Kucó. Második kiadás, Seneca Kiadó.

Cabré, J. (2000): Ballada. In: Viatge d'hivern. Fordította: Flamich Maria, Hoffmann Rita. Kézirat. Proa, Barcelona. 178-181.

Cabré, J. (2000): Gottfried Heinrich álma. In: Viatge d’hivern. Fordította: Flamich Maria, Hoffmann Rita. Kézirat Proa, Barcelona. 125-138.

Fogyatékosság-tudomány blog: URL: www.fogytud.blogspot.com Letöltés ideje: 2013. 08. 30.

Kafka, F.: Az átváltozás. Európa Diákkönyvtár, Európa Könyvkiadó, Budapest.

Karinthy Frigyes: Géniusz. URL: www.epa.oszk.hu/00000/00022/00031/00733.htm Letöltés ideje: 2013. 08. 30.

Kleege, G. (2006): Disabled Students Come Out: Questions without Answers. In: Thompson Ibrahim, Ch. (2011): An Anthology Of Disability Literature. Carolina Academic Press, Durham, North Carolina. 307-316.

McFerrin, B. - Quasthoff, Th. (2008): Bobby McFerrin \& Thomas Quasthoff at Jazz Fest Wien. URL: www.youtube.com/watch?v=RESX8YroSCQ Letöltés ideje: 2013. 08. 30.

Shakespeare, W.: Richard III. Európa Diákkönyvtár, Európa Könyvkiadó, Budapest.

Sinapi, J. P. (2001): Légyott a hetesen. Francia film

Steinbeck, J. E. (2008): Egerek és emberek. Aranytoll kötetek, Szeged.

Tímár Péter (2001): Vakvagányok. Magyar film

Tolkien, R. R. (2005): A gyürük ura: Smeagol megszelidítése. Európa Könyvkiadó, Budapest. Vujicic, N.: Te erős leszel a végén? URL: www.youtube.com/watch?v=Q4f_UNMNOMIA Letöltés ideje: 2013. 08. 30.

Wells, H. G.: Vakok országa. URL: www.mek.oszk.hu/00500/00532/html/02.html Letöltés ideje: 2013. 08. 30.

\section{A hallgatók vezetésével elemzett múvek:}

Andersen, H. Ch.: A rút kiskacsa.

Lessing, D. (2008): Az ötödik gyerek. Ulpius-ház, Budapest.

Groom, W. (1985) Forrest Gump címü regényének Zemeckis, Robert (1994) azonos címü filmje 